\title{
A Tax-Based Incomes Policy (TIP): What's It All About?
}

\author{
NANCY AMMON JIANAKOPLOS
}

\section{S} large. This is the essence of a plan devised by Governor Henry C. Wallich of the Federal Reserve Board and Sidney Weintraub of the University of Pennsylvania. ${ }^{1}$ Their proposal to use the tax system to curb inflation is called "TIP," an acronym for tax-based incomes policy. As inflation continues to plague the economy, many economists feel that the traditional tools of monetary and fiscal policy are inadecultate to handle the situation and have recommended direct measures to stop wage and price increases." The Wallich-Weintraub plan has received considerable attention as a policy measure which might be capable of dealing with the problem of inflation. ${ }^{3}$

Before adopting a program such as TIP, it is important to understand elearly how the proposal would operate and, more importantly, whether it would achieve the desired results. The first part of this article describes the functioning of TTP and the rationale for such a program as envisioned by Wallich

${ }^{1}$ Wallich and Weintraub first collaborated on this idea in Henry C. Wallich and Sidney Weintraub, "A Tax-Based Incomes Policy," Joumal of Economic Issues (June 1971), pp. 1-19.

"See, for example, "Another Weapon Against Inflation: Tax Policy," Business Week, October 3, 1977, pp. 94.96; "Debate: How to Stop Inflation, Fortune (April 1977), pp. 116-20; Lindley H. Clark, Jr., "Uneasy Seers: More Analysts Predict New Inflation Spiral or Recession in 1978," Wall Street Journal, December 2, 1977 .

${ }^{3}$ See, for example, U. S. Congtess, Congressional Budget Office, Recovery With Inflation, fuly 1977, p. 40; U. S. Cengress, Joint Economic Committee, The 1977 Midyear Reciets of the Economy, 95th Cong., 1 st sess., September 26, 1977, p. 76; "Well Cut Taxes Should Be Talored," New York Times, December 21, 1977. and Wentraub. The rest of the article is devoted to an assessment of whether TIP would accomplish its stated objectives.

\section{HOW WOULD TIP OPERATE?}

According to the plan presented by Wallich and Weintraub, TIP would be centered on a single wage guidepost established by the Govermment. The acceptable percentage wage increase could be set somewhere between the average increase in productivity throughout the economy (asserted to be around 3 percent) and some larger figure which incorporates all or part of the current rate of inflation. The ultimate aim of the guidepost is to bring wage increases in line with nationwide productivity increases.

The TIP guidepost is directed at wages only, although the tax is levied on corporate profits. The basic assumption behind TIP is that monetary and fiscal policies have been ineffective because they have not been able to prevent labor from obtaining wage increases in excess of productivity gains, even when there is significant unemployment in the economy. Furthermore, Wallich and Weintraub contend that empirical evidence supports the view that price in-

4Unless otherwise noted, all descriptions of TIP in this articte are based on Wallich and Weintrabu, "A Tax-Based fncomes Policy"; Henry C. Wallich, "Alternative Strategies for Price and Wage Controls," Journal of Economic lssues (Decenber 1972), pp. 89-104; Henry C. Wallich, "A Plan for Dealing With Inflation in the U.S." Washington Post, August 21, 1977; Sidney Weintraub, "An Incomes Policy to Stop Inflation," Lloyds Bank Reoiew (January 1971), pp. 1-1.2; and Sidney Weintranb, "Incomes Policy: Completing the Stabili" zation Triangle," Joumal of Economic lssues (December 1972), pp. 105-22. 
creases have been a constant markup over unit wage increases. Therefore, if wage increases can be kept down, price increases will also be held down.

The corporate income tax system would be employed to enforce the TIP guidepost. Corporations which grant wage increases in excess of the guidepost would be subject to higher corporate income tax rates based on the anount that wage increases exced the guidepost.

In order to understand how TIP would operate, consider the following example. Stppose the guidepost for wage increases is set at, say, 5 percent for a particular year. In the base year, Corporation $A$ had a total wage bill of $\$ 100,000$ and in the following year granted increases which brought its total wage bill to $\$ 108,000$ - an 8 percent increase. Assuming no change in either the number or composition of the employees, this 8 percent increase is 3 percentage points above the guidepost. This excess would then be multiplied by a penalty number. If, for instance, the penalty was set at 2 , the corporate tax rate of Comporation $A$ would be increased by 6 percentage points ( 3 percentage point excess times penalty number of 2 ). Thus, instead of paying 48 percent of its profits in taxes, the existing corporate tax rate, Corporation $A$ would have to pay 54 percent of its profits, as a penalty for acceding to "excessive" wage demands.

Wallich and Weintraub argue that because of competitive forces this additional tax could not be shifted forward to prices. They, therefore, believe that such a tax penalty would cause corporations to deal more firmly with labor. In their view the penalty would ultimately restrain the rate of wage increases and, hence, reduce the rate of inflation. "Since wage increases would be curbed, corporations would not have higher costs to pass through in the form of price increases, thereby eliminating a major "cost-push" element of inflation. Furthermore, since the incteases in incomes of workers would more closely approximate increases in productivity, there would be smaller in-

\footnotetext{
5See Richard A. Musgrave and Pegrgy B. Musgrave, Public Finance In Theory and Practice (New York: MeGraw-Hill Book Company, 1973), Chapter 18, pp. 415-29, who contend that empirical evidence is incondusive in detemining whether the corporate income tax is shifted.

fSturies by Yehuda Kotowitz and Riclard Portes, "The "Tax on Wage Increases": A Theoretical Analysis," Joumal of Public Lonomics (May 1974), pp. 113-32, and Peter Isare, "The Effectiveness of Using the Tax System to Citrb Inflationary Collective Bargains: An Analysis of the WallichWeintmb Plan" foumul of Political Economy (Nay-Jume $1973)$, pp. $729-40$, analyze the effect of TIP on an individ ual fim and concinde that theoreticaly TIP should lead to lower wage seftements for an individual frm.
}

creases in spending, reducing the "demand-pull" aspect of inflation.

Wallich and Weintraub acknowledge certain diffctlties in computing the corporation's wage bill. One method which they believe would overcome many of these difficulties would be to construct atz index of wages, rather than using the gross dollar figure. Using this method, wages, ininge benefits, and other related payments would be computed for each job classification and skill level and divided by the hours worked at each level. These wage figures would then be combined into an index weighted by the proportion of each of these classifications in the entire corporation. Changes in this index would then be compared to the guidepost in order to assess whether the corporation would be penalized.

Administrative problems are not neglected by Wal lich and Weintatub. They recognize that the tax laws must be specific and "airtight" in order to avoid loopholes. However, it is argued that TIP would not involve establishing a new bureaucracy. Most of the data necessary to administer TIP are already collected for corporate income tax and employee payroll tax purposes.

One of the principal mexits of TIP, in the view of Wallich and Weintraub, is that it would not interfere with the functioning of the market system. They argue that there would be no direct controls or distortions to the pricing mechanism. Firms would still be free to grant large wage demands, but would face the penalty of a higher corporate tax rate.

Rather than a short-term plan to curb inflation, TIP is envisioned to be a longterm means of reducing the rate of price increase. However, TIP is not intended to function by itself. Both Wallich and Weintraub see it as a supplement to "appropriate" monetary and fiscal policies. In addition, if labor contends that TIP would hold down wages while allowing profits to increase, Wallich proposes the implementation of an excess profits tax. This could be accomplished by increasing the basic corporate tax rate to keep the share of profits in national income constant.

\section{WOULD TIP WORK?}

The TIP proposal has two principal objectives:

(1) to curb intation, and

\footnotetext{
TOther adiuncts proposed for TP incinde a payroll tax credit designed to entice workers to accept lower wages. See Law" rence S. Seidman, "A Payroll Tax-Credit to Restrain Inlation", National 7rat Joumal (December 1976), pp. 398412.
} 
(2) to avoid interfering with the functioning of the market.

Given these aims of TIP, one can analyze whether TIP will, in fact, be able to accomplish its goals. Other issues raised by TrP, such as the costs of implementation and the ability of firms to avoid the tax penalty of TIP, will not be discussed here.

\section{Would TR Curb Infation?}

TIP is based on the assumption that most of the inflation in the economy is of a "cost-push" nature. Inflation occurs, according to this framework, because labor is able to attain wage increases in excess of increases in productivity. Business is not capable of resisting, or finds it does not pay to resist, labor's demands. Faced with higher costs, businesses pass these costs through in the form of higher product prices. As prices rise, further wage increases are granted, forming the basis of a wage-price spiral. TIP is proposed as a measure which will intervene in this process and bring inflation to a halt.

As the Congressional Budget Office stated in a recent study, the assumption that inflation is the result of "cost-push" is "a conjectural notion at best." A major challenge to the concept of "cost-push" rests on empirical evidence supporting an alternative theory of the cause of inflation. According to this other view, ongoing increases in the general price level (inflation) are primarily the result of excessive increases in the rate of monetary expansion. ${ }^{10}$ Lags exist between the time when the money stock is increased and when prices rise. In this framework, the observed relationship between the rate of wage increase and the rate of price increase is explained as part of the adjustment process through which prices increase in response to increases in the money stock. This view does not deny the "cost-push" phenomenon,

8For a discussion of implementation problems, see Gardner Ackley, "Okun's New Tax-Based Incomes-Policy Proposal," Survey Research Center, Institute for Social Research, The University of Michigan, Economic Outlook USA (Winter 1978 ) pp. 8-9. Althongh Ackley deals with the antininflation proposal put forward by Arthur Okun, he notes that the critique also applies to the Wallich-Weintraub proposal.

"Congressional Budget Ofice, "Recovery With Inflation," p. 41.

10Empirical support of this view for the period 1955 to 1971 is presented by Leonall C. Andersen and Deris S. Karnosky, "The Appropriate Time Frame for Controlling Monetary Ag" gregates: The St, Lous Evidence," Controlling Monetaty Aggregates II: The Inplementation, Federal Reserve Bank of Boston, Conference Sevies No.9, September $1972, \mathrm{pp} .147-$ 77. Adklitional evidence for the period 1971 to 1976 is foun in Denis $\$$. Kamosky, "The Link Between Momey and Prices - 1971-76," this Revieu (June 1976), pp. 17-23. but contends that it is consistent with the view that inflation is ultimately catused by money growth.11

When the stock of money is increased faster than the rate of increase in production, people find them selves with larger casli balances than they desire to hold. In order to bring their cash balances down to desired levels, they will spend the money, thereby bidding up prices on goods and services, and the general price level will rise. As long as the stock of money increases faster than the demand for money, inflation will persist, even if TIP manages to hold down wages temporarily.

Conversely, just as inflation is caused by excessive growth of the money stock, the only way to stop inflation is to reduce the growth of the money stock. As the rate of monetary expansion is reduced, people will have cash balances below their desired levels. They will reduce their mate of spending in order to build up these balances. As spending (demand) falls, the rate of inflation will decrease. Prices are "sticky", and just as it took several years to build up the current rate of inflation, it will take several years for inflation to wind down. One of the by-products of reducing inflation is a temporary idling of resources, since prices do not tend to be flexible in the short run. This is a cost of reducing inflation which must be borne, just as there are costs imposed on society as inflation mounts.

The idea that there are certain "key" wages in society, strch as union wages, to which other wages and prices adjust, confuses the motivation for increasing the money stock with the cause of inflation. ${ }^{12}$ If certain unions are able to attain large wage increases, even in the face of falling demand, the prices of the products produced by this labor will increase. As prices increase, less of this product will be demanded and the use of the resources (labor and capital) which produce this product will be decreased. Unemployment will rise as resources are freed to work in the production of other products whose prices are lower. The relative prices of products will change, but the average price level will be unchanged.

1. See Leonall C. Andersen and Denis S. Karnosky, "A Monetary Enterpretation of Inflation" in Joel Popkiz, ed., Analysis of Inflation; 1965-1974, Studies in Tncome and Wealth, Vol. 42, National Bureau of Economic Research, Ine. (Cambridge, Massachusets: Ballinger Publishing Company, 1977), pp. $11-26$.

12This argument draws on Armen A Alchian and William R. Allen, University Economits: Elements of Inquivy (Belmont, California: Wadsworth Publishing Company, Inc, 1972), pp. $684-85$. 
However, if the Federal Reserve policymakers keep a close watch on these "key" industries and see an increase in idle resources (unemployment) in these industries, they may take actions to alleviate the unemployment by increasing the money stock. The increases in spending resulting from monetary expansion will bid up average prices and return relative prices to a position similar to that prior to the granting of the wage demands. It was as a consequence of the excessive wage demands that policy actions were motivated, but it was monetary expansion which catsed the subsequent inflation.

Some proponents of TIP base their support on the belief that TIP will reduce expectations of inflation. Lower expectations of inflation in the future, according to this view, will lead to lower demands for wage increases and eventually lower prices. However, expectations of inflation do not cause inflation. ${ }^{13}$ It is ongoing inflationary forces in the economy, excessive rates of monetary expansion, which lead to expectations of future inflation. Curbing inflationary expectations requires curbing the underlying forces which cause them.

Wallich and Weintraub agree that TIP is a supplement to, not a substitute for, "appropriate" monetary and fiscal policy. However, the character of their "appropriate" monetary policy is questionable. In the basic article which outlined TIP, Wallich and Weintraub stated, “. . . the proposal is conceived as a supplement to the familiar monetary-fiscal policies so that the economy might operate closer to full employment without the inflationary danger of excess demand and "overheating." "14 Indeed, in a later article Weintraub is more specific: "Given a suitable incomes policy to align wages (and salaries) to productivity, monetary policy would be released to make its contribution to full employment. . Full employment requires ample money supplies for its sustenance."1.5 Thus, it appears that "appropriate" monetary poliey, in the view of Wallich and Weintraub, is expansionary; however, a restrictive monetary policy is necessary to curb inflation.

This disparity in determining the appropriate character of monetary policy points out another problem with TIP. Given the lag time involved in the func-

19Weintraub supports this contention in Weintraub, "Incomes Policy: Completing the Stabilization Triangle," p. 116.

14Wallich and Weintrab, "A Tax-Based Incomes Policy," p. 1.

15Weintrab, "Incomes Policy; Completing the Stabilization Triangle," p. 110. tioning of monetary policy, it might appear in the short run that TIP is, at least temporarily, holding down prices. If, at the same time, the Federal Reserve increases the rate of monetary expansion, inflationary pressures will actually be augmented. An incomes policy, such as TIP, gives policymakers the illusion of taking corrective measures against inflation when, in fact, reducing the rate of monetary expansion is the only way to accomplish that goal. In summary, it appears that TIP would not be effective in reducing inflation and could make matters worse by fostering inappropriate monetary policy.

\section{Would TP Interfere Winh whe Manet?}

Wallich and Weintraub argue that TIP would not interfere with market pricing because no ceilings are placed on any wages or prices. TIP operates through the tax system, yet it is based on a single guidepost for every firm and industry. They contend that a single guidepost is appropriate because in competition all comparable workers would eam the same wage. TIP, therefore, is only imposing what competition would achieve.

The problem with this argument is that it is only true if all industries are in equilibrium and remain there. In a growing, changing economy, equilibrium prices and wage rates are changing. Prices and wages are constantly moving toward new equilibria; hence, there is no reason to believe that each sector in the economy would be at equilibrium when TIP was imposed or would remain there afterward. In the U. S. economy, demands and tastes of consumers are constantly shifting and the technology and products offered by business are also changing. As a consequence, the equilibrium prices of some goods are rising (houses, for example) while others are falling (electronic calculators). In addition, some firms are growing, making large profits, and seeking additional labor, while others are declining, earning very little profit, and contracting their labor forces.

Imposing a single wage guidepost would distort the price system. It does not matter whether the guidepost is imposed through the tax system or by direct fines and penalties. Those firms which are growing or are adapting to changing consumer tastes have an incentive to hire scarce resources (capital and labor) away from other firms, but they would be penalized either through a lower rate of return, if they grant "excess" wage demands, or by a barrier to growth if they adhere to the guidepost. Consequently, in some instances labor would not be compensated in accord 
with the demand for its services. In other cases, firms would not be able to attract all the labor they desired. Relative prices would, therefore, be distorted by the establishment of a single guidepost for all firms and industries.

The TIP proposal would lead to a misallocation of resources. Prices, when allowed to operate freely, offer signals of where demand is increasing and where demand is falling. Resources move to those industries or firms where they will receive the highest compensation. The TIP proposal would obscure these price signals and, hence, resources would not move to where they would be used most efficiently. The economy would suffer since production would be lower than it would be otherwise.

The distortions in the economy caused by TIP could have a very long lasting effect. Capital (plant and equipment) is allocated by the market to those firms which have the highest rate of return. The TIP proposal would reduce the rates of return of those firms which are growing, and capital would not be adequately allocated to them. Capital generally kends to have a relatively long life. Once it is misallocated, as a result of TIP, it would not be easy to reallocate it to a more efficient use. Thus, TIP conld have serious long-term comsequences, as a result of the distortions it would cause in the price system.

\section{CONCLUSION}

TIP is an incomes policy designed to reduce inflation without interfering with the market system. The essence of the proposal is to subject corporations to higher comporate income tax rates if they granted pay increases in excess of a single Covernment-mandated guidepost.

TIP would not be successful in reducing the rate of inflation becatse it is based on the premise that inflation is largely a "cost-push" phenomenon - higher wages leading to higher prices, which lead to still higher wages. Inflation, however, is caused primarily by excessive growth of the money stock. The TIP proposal, therefore, deals only with the symptoms of inflation, rather than attacking inflation at its root.

TIP would distort the market pricing system becanse the imposition of a single wage guidepost would not allow relative prices to adjust fully to change. This would lead to inefficiencies and a lower level of production than would be otherwise attainable.

Inflation is a serious problem, and there are no magic solutions. There may be a temporary reduction in the apparent rate of inflation with TIP, but eventually leaks will develop in the system and prices will rise anyway. The only way to stop inflation is to reduce the rate of monetary expansion.

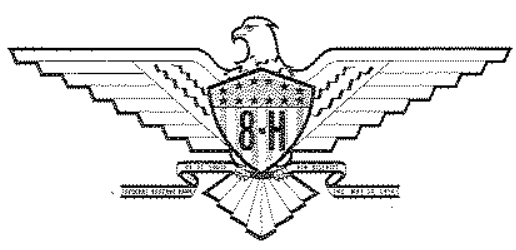

